\title{
インフルエンザA/H1N1pdm09とA群溶連菌の重複感染か ら血球貪食症候群をきたした1例
}

\author{
小野雄一郎 小野 真義 伊藤 岳 \\ 佐野秀宮本 哲也当麻 美樹
}

\begin{abstract}
要約：インフルエンザ A/H1N1pdm09による重症病態は数多く報告されている。インフルエ ンザ感染に劇症型 $\mathrm{A}$ 群溶連菌感染症，血球貪食症候群を併発した 1 例を報告する。症例は 24 歳の男性。高熱, 意識障害で前医を受診, 精査の結果, インフルエンザ感染による多臓器障 害と診断され，当院に紹介搬送となった。来院時，呼吸不全・循環不全を呈しており，心機 能の著明な低下も認めたため, 人工呼吸器管理, 補助循環を導入した。また, 臨床所見から 血球領食症候群を併発していると判断し, 免疫抑制療法や血漿交換を施行したが, 溶連菌菌 血症も併発し，救命することができなかった。死後の骨髄検体で血球貪食像や溶連菌の組織 浸潤を認めた。インフルエンザは日常診療でしばしば遭遇する疾患であるが，ときに致死的 な合併症をひき起こすため, 注意すべきである。
\end{abstract}

Key words: (1)influenza A/H1N1pdm09, (2) group A streptococcus, (3)hemophagocytic syndrome

\section{はじめに}

インフルエンザ A/H1N1pdm09 (いわゆるブタ由来 新型インフルエンザのことであるが, 世界保健機関に より現在はこの名称に統一されている)の世界的大流 行は多くの重症病態1),2)を引き起こし, 様々な症例が 報告されている。インフルエンザ感染の重症化は, 脳 炎や心筋炎, ウイルス性肺炎による acute respiratory distress syndrome (ARDS) などウイルス感染自体に よる合併症によるものと, 基礎疾患の増悪によるもの に分けられる。今回我々は, このインフルエンザ感染 にA群溶連菌感染症が重複し, さらに血球貪食症候群 (hemophagocytic syndrome, HPS) が続発, 急激な経 過をたどり死亡した 1 例を経験したので報告する。

\section{症 例}

患者：24歳, 男性。

主訴：意識障害。

既往歴 : 強迫神経症の診断に対して, 近医で抗精神 病薬の投与を受けていた。普段は自宅自室にこもりが
ちで，家族もあまり様子を把握していなかった。

現病歴：来院 2 日前より発熱・咳嗽を認めたが, 自 宅で様子を見ていた。来院当日，自らバイクで病院へ 出かけようとしている本人の様子がおかしいことに家 族が気付き, 救急車を要請, 前医へ救急搬送された。 前医でインフルエンザ簡易検査 $\mathrm{A}$ 型陽性・好中球減 少症・急性腎不全・低酸素血症を認め, 重症インフル エンザ感染と診断され, 当院に紹介搬送となった。

来院時身体所見：意識レベルはGlasgow coma scale でE2V1M4, Japan coma scaleでII-30であった。呼 吸数は $40 / \mathrm{min}$, 心拍数は $140 / \mathrm{min}$ であった。血圧は 測定不能であり, かろうじて頸動脈の拍動のみ触知可 能であった。経皮酸素飽和度は, 未梢循環が非常に悪 く測定不能であった。眼球結膜は充血が強く, 体幹部 に出血斑, 下肢にはまだらな発赤が見られた。胸部聴 診では両側で水泡ラ音が聴取された。

来院時検査所見：動脈血ガス分析では, リザーバー 付きマスクで酸素 $15 \mathrm{l} / \mathrm{min}$ 投与下で, $\mathrm{pH} 7.193$, $\mathrm{PaCO}_{2} 60.9$ mmHg, $\mathrm{PaO}_{2} 64.3 \mathrm{mmHg}, \mathrm{HCO}_{3}{ }^{-} 22.5$ $\mathrm{mmol} / l, \mathrm{BE}-6.5 \mathrm{mmol} / l$, 乳酸 $8.3 \mathrm{mmol} / l$ と, II 型 


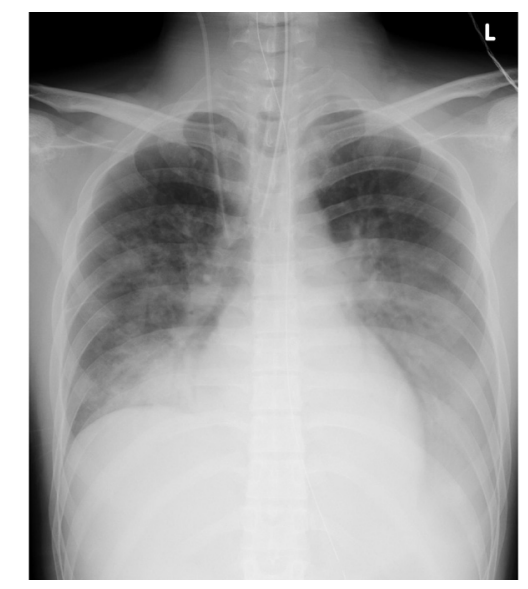

Fig. 1 Chest radiography on admission (a)

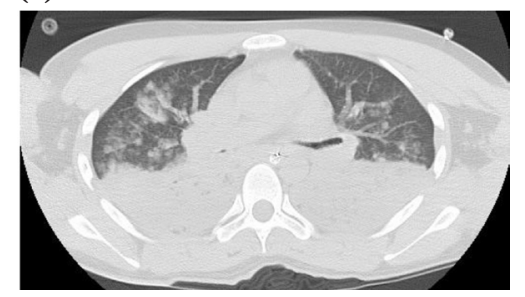

(b)

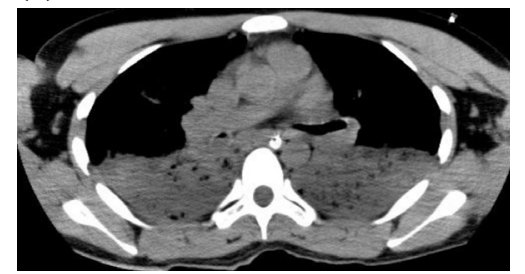

Fig. 2 Chest CT at the carina level on admission

Lung window(a) shows ventral ground glass opacity. Mediastinum window(b) shows dorsal atelectasis.
呼吸不全, 著明な混合性アシドーシスを認めた。血液 一般検査ではWBC $930 / \mu l, \mathrm{Hb} 14.7 \mathrm{~g} / \mathrm{d} l, \mathrm{Ht}$ $43.7 \%$, 血小板数 $9.8 \times 10^{4} / \mu l$ と, 白血球と血小板に 減少を認めた。血液生化学検査では尿素窒素 $40 \mathrm{mg} /$ $\mathrm{d} l$, 血清クレアチニン $3.45 \mathrm{mg} / \mathrm{d} l$ と腎機能障害を認め, CRPも $40.83 \mathrm{mg} / \mathrm{d} l$ と高值を示した。また, AST 69 $\mathrm{IU} / l$, LDH $677 \mathrm{IU} / l$, CK 1,906 IU/l, CK-MB 46 IU/ $l$, トロポニン I $0.176 \mathrm{ng} / \mathrm{m} l$ と心筋逸脱酵素を含む筋 原性逸脱酵素の上昇を認めた。胸部X線写真 (Fig. 1) では両側下肺野を中心とした浸潤影を認めた。胸部単 純 CT (Fig. 2) では両側肺野背側は無気肺を形成し, 腹側には浸潤影, ground glass opacity (GGO) が見ら れた。心臓超音波検査では, びまん性の心収縮能の著 明な低下を認め, 駆出率は $20 \%$ を下回っていたが, 心 囊液貯留は認めなかった。心電図は著明な洞性頻脈な ど非特異的な変化のみであった。

来院後経過 (Fig. 3) : 初療室で直ちに気管挿管し, 酢酸リンゲル液 $2,000 \mathrm{~m} l$ の急速投与, ドパミン・ドブ タミン各 $10 \mu \mathrm{g} / \mathrm{kg} / \mathrm{min}$ の投与にて, 一旦血圧が上昇 したが, 来院後 2 時間で再び血圧低下, 代謝性アシドー シスも進行した。そのため, 補助循環の導入を決定し, percutaneous cardiopulmonary support (PCPS), intra-aortic balloon pumping (IABP) を導入した。こ のとき同時に施行した冠動脈造影検査では異常は認め られなかった。インフルエンザに対しては抗インフル エンザ薬peramivirを投与し, 2 次感染による肺炎の 合併も疑い抗菌薬 pazufloxacin 追加した。2系統の 血球減少症に対してはgranulocyte colony-stimulating factor (G-CSF) 製剂や輸血製剤の投与を行った。また 心筋炎や脳炎といった病態を考慮し $\gamma$ グロブリン製剤 やメチルプレドニゾロン $1,000 \mathrm{mg}$ 投与のステロイド パルス療法も開始した。来院からほぼ無尿であり, 代
謝性アシドーシスも認めたため, 来院後約 6 時間で血 液浄化療法も導入した。来院 2 日目, 来院時に採取し た血液培養よりグラム陽性レンサ球菌が検出され, グ ラム染色で溶連菌群が疑われたため抗菌薬 penicillin Gを追加投与, また臨床的にHPSを疑い, 血漿交換を 追加した。血漿交換は 4 時間で新鮮凍結血漿 $40 \mathrm{U}$ 置換した。来院 3 日目, CK-MB $538 \mathrm{IU} / l$, トロポニン I $1.97 \mathrm{ng} / \mathrm{m} l$ と心筋逸脱酵素は上昇を続けたが, 今ま で認めなかった動脈圧ラインの自己心拍圧波形の出現 や心臓超音波検査での左室壁運動の改善があり, 心機 能の改善を示す所見が得られた。しかし他の蔵器障害 は進行し, 各種臓器サポートを駆使しても代謝性アシ ドーシスの進行を食い止めることができず, 来院後約 45 時間で死亡した。来院時の咽頭粘液の polymerase chain reaction (PCR) 検査でインフルエンザA/ H1N1pdm09 陽性との報告が保健所よりあり, 血液培 養の結果は最終的にA 群 $\beta$ 溶連菌と確定された。死 後に採取した骨髄検体 (Fig. 4) からは血球を貪食する 組織球が見られ, また著明な溶連菌の骨髄内への浸潤 像も見られた。インフルエンザとA群溶連菌の重複 感染によるHPS と診断した。

\section{考 察}

本症例はインフルエンザウイルス感染に溶連菌菌血 症が合併し, それが原因でHPSにまで至ったと考え る。個々の病態は稀ではあるが, 従来のインフルエン ザや近年大流行したインフルエンザ A/H1N1pdm09 の合併症としては多くの報告がなされている3)。

まず溶連菌感染の合併について, インフルエンザ感 染は $\mathrm{A}$ 群溶連菌感染の劇症化に関連があるとされ, 動 物実験による証明4)や症例報告5)がある。これはイン フルエンザ感染細胞に対して A 群溶連菌の親和性が 


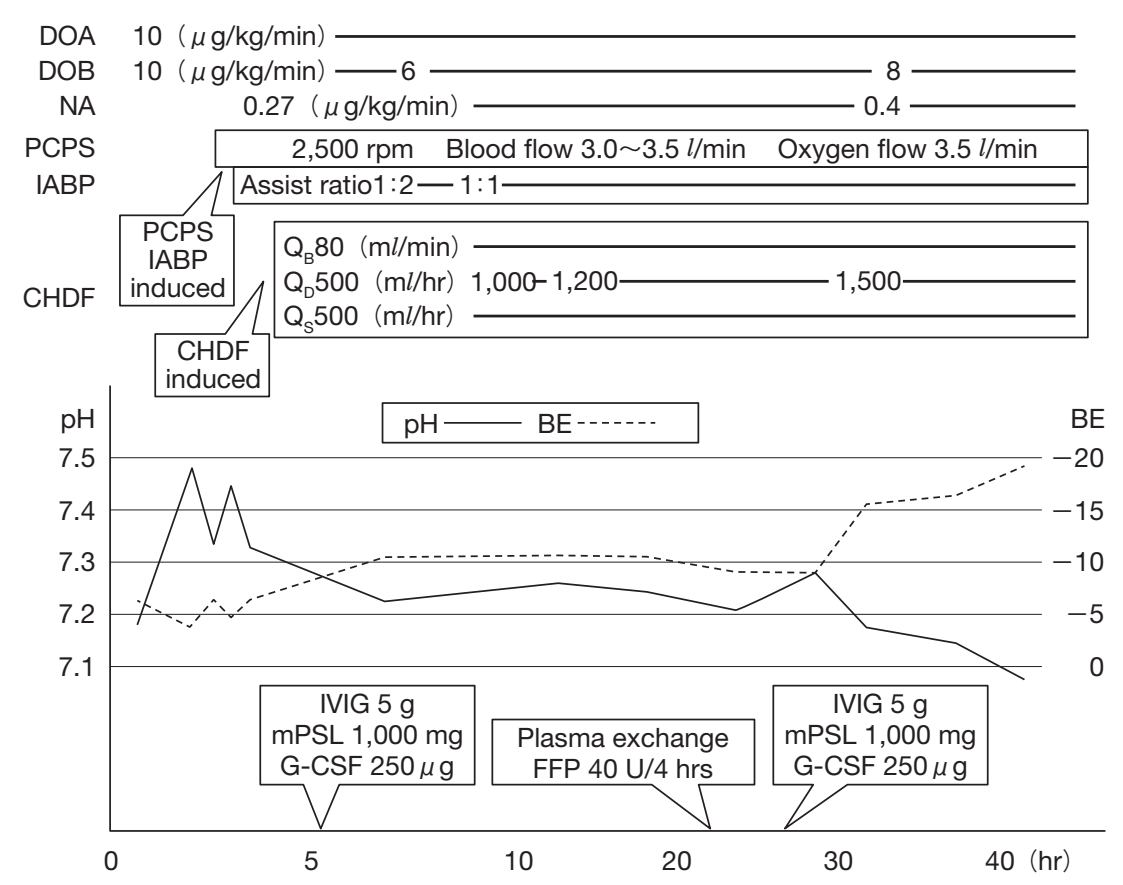

Fig. 3 Clinical course

CHDF, continuous hemodiafiltration; DOA, dopamine; DOB, dobutamine; FFP, fresh frozen plasma; G-CSF, granulocyte colony-stimulating factor; IABP, intra-aortic balloon pumping; IVIG, intravenous immunoglobulin; mPSL, methylprednisolone; NA, noradrenaline; PCPS, percutaneous cardiopulmonary support; $\mathrm{Q}_{\mathrm{B}}$, blood flow rate; $\mathrm{Q}_{\mathrm{D}}$, dialysis flow rate; $\mathrm{QS}$, replacement flow rate.

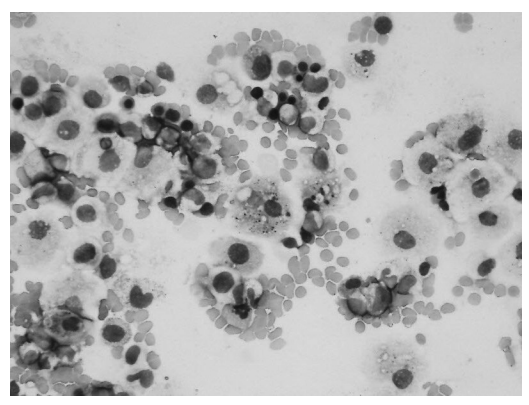

Fig. 4 Bone marrow necropsy shows histiocytes phagocytosing red blood cells

高いことが原因であるとされている6)。これはインフ ルエンザA/H1N1pdm09のパンデミックに際しても 劇症型 $\mathrm{A}$ 群溶連菌感染症の合併症例が報告されてお り, Jean らの報告では重複感染症例 10 例中 7 例の高い 死亡率が報告されている7)。

また本症例では, 重症感染症の経過中に多系統の血 球減少を認め, 多臓器障害に陥ったため, HPSの可能 性を考慮し治療を行った。HPSは様々な原因によっ て発症する病態で, 原因や年龄によって異なる診断基 準が諸家により提唱されている8)。感染症が原因であ る場合は続発性HPSに分類され, cytokine stormが原 因であると考えられている。診断には, (1) 1 週間以上
続く発熱, (2)2系統以上の血球減少, (3)骨髄中の組織 球の増加, (4)血球荟食像の確認といった条件を満たす ことが必須である。本症例は, 経過が非常に短く完全 には合致しないが, 病理組織像で血球貪食細胞があり, 発熱, 多系統の血球減少を認めたため, インフルエン ザウイルスおよび溶連菌の重複感染によるHPS と診 断した。治療は原疾患への対処と高サイトカイン血症 に対する免疫学的制御である。感染症に対する治療だ けで軽快する場合からあらゆる治療を行っても致死的 な経過をとる場合まで, 経過は様々である。Beutelら は, 4 ケ月間にハノーバー大学病院ICUで診療したイ ンフルエンザ症例 25 例中 9 例にHPSを認め, うち8例 が死亡したと報告している9)。治療は, ステロイドパ

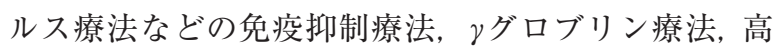
サイトカイン血症に対する血漿交換などが有用である とされている。本症例でも有用と報告されているもの をほぼ全て行った。

補助循環を必要とする心機能低下が見られたことに ついては, インフルエンザによる心筋炎の可能性を考 えなければいけない。ウイルス性心筋炎はインフルエ ンザA/H1N1pdm09の大流行時に非常に注目された 合併症である10)。しかし本症例を心筋炎と確定する には ${ }^{11)}$, 特徵的な心電図変化や心囊液貯留などの所見 
を欠き，また敗血症やアシデミアなど，他に心機能低 下をきたす病態が併存したため, 心機能低下の原因を 確定することはできなかった。本症例の診断確定には 心筋の組織学的所見が必要であった。

本症例を救命できなかった理由としては,インフル エンザ, A群溶連菌感染, どちらか一方の単独の重症 病態であっても非常に重篤であるにもかかわらず, そ れが重複してしまった点であると考える。予防接種や 早期の受診行動があれば救命できた可能性がある。イ ンフルエンザとA群溶連菌感染の重複感染や HPS と いう病態は十分認識されているとはいえず, これから さらなる症例の蓄積と認識の向上が必要であると思わ れた。

本稿のすべての著者には規定されたCOIはない。

\section{文 献}

1) Writing Committee of the WHO Consultation on Clinical Aspects of Pandemic (H1N1) 2009 Influenza, Bautista E, Chotpitayasunondh $\mathrm{T}$, et al. Clinical aspects of pandemic 2009 influenza A (H1N1) virus infection. N Engl J Med 2010;362:1708-19.

2) 厚生労働省. 今冬のインフルエンザの発生動向〜医療従事 者向け疫学情報〜Ver. 2 in 2011. Available from: http:// www.mhlw.go.jp/bunya/kenkou/kekkaku-kansenshou04/ pdf/110210-03.pdf
3) Rothberg MB, Haessler SD. Complications of seasonal and pandemic influenza. Crit Care Med 2010;38(4 Suppl):e91-7.

4) Okamoto S, Kawabara S, Nakagawa I, et al. Influenza A virus-infected hosts boost an invasive type of Streptococcus pyogenes infection in mice. J Virol 2003;77: 4104-12.

5) Bhat N, Wright JG, Broder KR, et al; Influenza Special Investigations Team. Influenza-associated deaths among children in the United States, 2003-2004. N Engl J Med 2005;353:2559-67.

6) 浜田茂幸, 中川一路, 川端重忠. 劇症型感染症をひき起こ す $\mathrm{A}$ 群レンサ球菌のゲノム解析と病原性因子．蛋・核・酵 素 2005;50:253-61.

7) Jean C, Louie JK, Glaser CA, et al. Invasive group A streptococcal infection concurrent with $2009 \mathrm{H} 1 \mathrm{N1}$ influenza. Clin Infect Dis 2010;50:e59-62.

8) 熊倉俊一. HPSの病態・診断・治療. 日血栓止血会誌 2008:19:210-5.

9) Beutel G, Wiesner O, Eder M, et al. Virus-associated hemophagocytic syndrome as a major contributor to death in patients with 2009 influenza A (H1N1) infection. Crit Care 2011;15:R80.

10) Ukimura A, Izumi T, Matsumori A, et al; Clinical Research Committee on Myocarditis Associated with 2009 Influenza A (H1N1) Pandemic in Japan organized by Japanese Circulation Society. A national survey on myocarditis associated with the 2009 influenza A (H1N1) pandemic in Japan. Circ J 2010;74:2193-9.

11) 和泉 徹班長. 急性㧍よび慢性心筋炎の診断・治療に関す るガイドライン (2009年改訂版)。日本循環器学会編。循 環器病の診断と治療に関するガイドライン $(2008$ 年度合同 研究班報告). Available from: http://www.j-circ.or.jp/ guideline/pdf/JCS2009_izumi_h.pdf

\section{Abstract \\ A case of hemophagocytosis with co-infections of influenza and group A streptococcus}

Yuichiro Ono, Masayoshi Ono, Takeshi Ito, Shigeru Sano, Tetsuya Miyamoto, Yoshiki Tohma

Acute Care Medical Center, Hyogo Prefectural Kakogawa Medical Center

203 Kanno-cho Kanno, Kakogawa, Hyogo 675-8555, Japan

There have been many cases of infection caused by influenza A/H1N1pdm09. We encountered a case of hemophagocytosis with co-infections of influenza and group A streptococcus. A 24-year-old man was referred to us with multiple organ dysfunction syndrome due to influenza infection. When he was transferred to the previous hospital, he had high fever and disturbance of consciousness. On admission to our hospital, he showed respiratry and cardiac failure. His heart function was severely decreased, and we initiated mechanical ventilation, percutaneous cardiopulmonary support, and intra-aortic balloon pumping. Clinical findings of neutropenia, thrombocytopenia, and disseminated intravascular coagulation suggested a complication of hemophagocytosis; therefore, we tried immunosuppressive therapy and plasmapheresis. However, group A streptococcal bacteremia also occuered, and the patient expired in approximately 2 days. Necropsy showed histiocytes phagocytosing red blood cells and severe streptococcal invasion. Influenza is a very common disease. However, fatal complications may occur on rare occasions.

Key words: (1)influenza A/H1N1pdm09, (2) group A streptococcus, (3) hemophagocytic syndrome 